\title{
MBSP1: a biosurfactant protein derived from a metagenomic library with activity in oil degradation
}

\author{
Sinara Carla da Silva Araújo ${ }^{1}$, Rita C. B. Silva-Portela ${ }^{1}$, Daniel Chaves de Lima ${ }^{1}$, \\ Marbella Maria Bernardes da Fonsêca ${ }^{1}$, Wydemberg J. Araújo ${ }^{1}$, Uaska Bezerra da Silva ${ }^{1}$, \\ Amanda P. Napp ${ }^{2}$, Evandro Pereira², Marilene H. Vainstein ${ }^{2}$ \& \\ Lucymara Fassarella Agnez-Lima $\mathbb{1}^{1 *}$
}

\begin{abstract}
Microorganisms represent the most abundant biomass on the planet; however, because of several cultivation technique limitations, most of this genetic patrimony has been inaccessible. Due to the advent of metagenomic methodologies, such limitations have been overcome. Prevailing over these limitations enabled the genetic pool of non-cultivable microorganisms to be exploited for improvements in the development of biotechnological products. By utilising a metagenomic approach, we identified a new gene related to biosurfactant production and hydrocarbon degradation. Environmental DNA was extracted from soil samples collected on the banks of the Jundiai River (Natal, Brazil), and a metagenomic library was constructed. Functional screening identified the clone $3 \mathrm{C6}$, which was positive for the biosurfactant protein and revealed an open reading frame (ORF) with high similarity to sequences encoding a hypothetical protein from species of the family Halobacteriaceae. This protein was purified and exhibited biosurfactant activity. Due to these properties, this protein was named metagenomic biosurfactant protein 1 (MBSP1). In addition, E. coli Rosetta ${ }^{\mathrm{TM}}$ (DE3) strain cells transformed with the MBSP1 clone showed an increase in aliphatic hydrocarbon degradation. In this study, we described a single gene encoding a protein with marked tensoactive properties that can be produced in a host cell, such as Escherichia coli, without substrate dependence. Furthermore, MBSP1 has been demonstrated as the first protein with these characteristics described in the Archaea or Bacteria domains.
\end{abstract}

Surfactants are amphipathic compounds that have a hydrophobic moiety that is directed towards the surface and a hydrophilic portion that is directed towards the solution ${ }^{1}$. These amphiphilic molecules can reduce surface tension at air/water and oil/water interfaces ${ }^{2,3}$. Surfactants produced by organisms are called biosurfactants, which are extracellular products or components within the cell membranes of prokaryotes and eukaryotes ${ }^{1,4,5}$. Biosurfactants are classified into four major categories: glycolipids, fatty acids, lipopeptides, and polymeric types. These categories are represented by amphipathic polysaccharides, lipopolysaccharides, lipoproteins, fatty acids, or complex mixtures of these biopolymers. In general, the synthesis of biosurfactants involves elaborate genetic systems, including operons, non-ribosomal peptide synthetases, and/or multiprotein assembly complexes ${ }^{6-9}$.

The synthesis of biosurfactants occurs in the presence of different substrates as a carbon source. To reduce production costs, cheaper substrates have been used. The most commonly used substrates for biosurfactant production are agro-industrial products such as molasses, marc, or vegetable oils ${ }^{6-8}$. Rhamnolipids and surfactin are among the best studied biosurfactants. Rhamnolipids are glycolipids first discovered in Pseudomonas aeruginosa, which are formed by the bonding between a rhamnose moiety and a 3-(3-hydroxyalkanoyloxy)alkanoic acid (HAA) fatty acid tail. The essential enzymes involved in this pathway are RhlA, RhlB, and RhlC, which are under quorum sensing control. RhlA catalyses the formation of HAA using $\beta$-hydroxydecanoyl-ACP as a precursor. RhlB is a rhamnosyltransferase that catalyses the bond between HAA and dTDP-L-rhamnose, resulting in the formation of mono-rhamnolipid. The enzyme RhlC adds a second rhamnose moiety to mono-rhamnolipids forming di-rhamnolipids ${ }^{10}$.

${ }^{1}$ Department of Cellular Biology and Genetics, Universidade Federal do Rio Grande do Norte, Natal, Rio Grande do Norte, Brazil. ${ }^{2}$ Center of Biotechnology, Universidade Federal do Rio Grande do Sul, Porto Alegre, Rio Grande do Sul, Brazil.*email: Ifagnez@ufrnet.br 
Surfactin is a cyclic lipopeptide discovered in Bacillus sp. It is a heptapeptide attached to a $\beta$-hydroxy fatty acid chain forming a cyclic lactone ring structure. The synthesis of surfactin is accomplished by a nonribosomal peptide (NRP) synthetases system, encoded by the $\operatorname{srfA}$ operon, which contains three genes ( $\operatorname{srf} A$, $\operatorname{srf} B$, and $\operatorname{srfC})$, controlled by quorum sensing system ${ }^{6,9}$.

Biosurfactants have several biotechnological properties; for example, biosurfactants are capable of reducing surface and interfacial tension. Additionally, biosurfactant properties have been shown to exhibit emulsification, de-emulsification, dispersion, solubilisation, and mobilisation. These properties permit the use of biosurfactants in the environmental field for hydrocarbon biodegradation and bioremediation. To date, the largest market for biosurfactants is the oil industry, mainly due to its wide array of applications such as bioremediation and dispersion of oil spills, removal and mobilisation of oil residues in storage tanks, and improved oil recovery. Nevertheless, biosurfactant applications in other industries, such as pharmaceutical, cosmetic, and food, are broadly dispersed ${ }^{2,11-14}$.

Biosurfactants offer many advantages over synthetic surfactants; for example, ecological acceptability due to low toxicity and high biodegradability ${ }^{15-17}$, effectiveness in a wide range of temperatures, stability under extreme conditions (e.g., $\mathrm{pH}$ and salinity) ${ }^{1,18,19}$, and higher efficiency than synthetic surfactants ${ }^{20}$. Despite these advantages, the production of biosurfactants at a large scale remains an expensive procedure, in part because of complicated extraction and purification processes, as well as the dependence on suitable substrates for their production $^{7,8}$.

Microorganisms are the primary source of biosurfactants; however, our understanding regarding the diversity of genes and mechanisms related to biosurfactant production is solely based on cultivable microorganisms, which represent less than $1 \%$ of the diversity of known microbial species ${ }^{21}$. In this context, metagenomic approaches may demonstrate to be a powerful technology for discovering new enzymes and other valuable biomolecules produced by non-cultivable microorganisms. Specifically, functional screening in metagenomic libraries, which has shown to be useful for discovering new genes since sequence homology is not required for gene identification $^{22,23}$. Despite these advantages, large-scale production of biosurfactants remains to be an expensive procedure, in part because of the complicated extraction and purification processes as well as the dependence on suitable substrates for their production ${ }^{24}$. In this study, we described the identification and characterisation of a new gene, a homolog to a hypothetical protein from the domain Archaea, which represents the first surfactant protein from this domain.

\section{Results}

Identification of a new gene related to surfactant production. The metagenomic library was obtained from a soil sample from the Jundiaí River (Natal, Brazil), which showed intermittent drainage and salinity reaching four times seawater concentrations. In total, 1,240 clones were screened through a functional selection for the detection of clones with surfactant activity and petroleum degradation. One clone, named 3C6, showed positive results in the drop collapse, emulsification, oil dispersion assays, and hydrocarbon degradation test. Due to these positive results in the functional screening, this clone was selected for functional characterisation described in this study. Sequence analysis of clone 3C6 revealed a $1.4 \mathrm{~kb}$ insert containing two open reading frames (ORFs), with 897 and $348 \mathrm{bp}$, respectively. In this study, we described the functional characterisation of the first ORF (Supplementary Fig. S1). The $897 \mathrm{bp}$ ORF encodes a polypeptide of 298 amino acids with an estimated weight of $31 \mathrm{kDa}$ and a theoretical isoelectric point $(\mathrm{pI})$ of 4.40 . This sequence showed a high similarity with hypothetical proteins of the family Halobacteriaceae. A total of 20 homologous proteins with $80 \%$ or more identity with 3C6 ORF1 were selected, all from organisms belonging to the Halobacterium class. This ORF also showed a $90 \%$ identity with a hypothetical protein from Natrialba taiwanensis in BLASTP (Supplementary Table S2).

Phylogenetic trees showed that 3C6 ORF is indeed related to these hypothetical proteins. This ORF was grouped with Haloferax lucentense and Halorubrum litoreum in the same branch. The bootstrap analysis demonstrated that this sequence is more similar to H. lucentense. The same result was obtained with Neighbour-Joining (Fig. 1A), maximum likelihood, and maximum parsimony methods (Supplementary Fig. S2).

The genomic context of this hypothetical protein was analysed in members of the family Halobacteriaceae using Absynte software (Fig. 1B). Synteny of 3C6 homologs were observed in some species. In general, the genomic context shows hypothetical proteins around 3C6 homologs with unknown functions. Since no conserved protein domains were identified in the 3C6 ORF or its homologs, a structural similarity search was performed using predictor servers PHYRE2 and PredictProtein. Data obtained with PHYRE2 showed a very low (non-statistical) similarity with a ribosomal protein (confidence of 70.3) and rubredoxin-like (confidence of 63.4) (Table 1). The PredictProtein software results also indicated structural homology of ORF 3C6 with rubredoxin-like protein, but with low confidence values.

Using PredictProtein software, it was possible to obtain alignment with 31 proteins from the UniProt database, being all hypothetical proteins from the Archaea domain. The most abundant amino acids in the protein were alanine (13.09\%), glycine (9.06\%), aspartic acid (9.06\%), and glutamic acid (8.05\%). Prediction of accessibility to the solvent showed that $62 \%$ of residues were wholly exposed, while $32 \%$ were buried within the protein core. The physicochemical properties of the amino acid sequence revealed a transmembrane helix located at the $95^{\text {th }}$ residue to the $112^{\text {th }}$, with a size of 18 amino acid residues-long.

The prediction of 3C6 subcellular localisation, considering Archaea, Bacteria, and Eukaryote domains, resulted in the following: secreted ( $100 \%$ confidence), periplasm ( $26 \%$ confidence), and nucleus ( $35 \%$ confidence). Disorder prediction using the Predictor of Natural Disordered Regions (PONDR ${ }^{\circledR}$ ) tool (Molecular Kinetics, Inc., Indianapolis, IN, USA) showed 131 disordered residues, corresponding to $43.96 \%$ of the $3 \mathrm{C} 6$ entire structure. These residues are distributed in nine central disordered regions (Fig. 2). The amino acid sequence also showed $36.91 \%$ of residues to be hydrophobic, $17.11 \%$ acidic, $10.07 \%$ basic, and $35.91 \%$ neutral. 

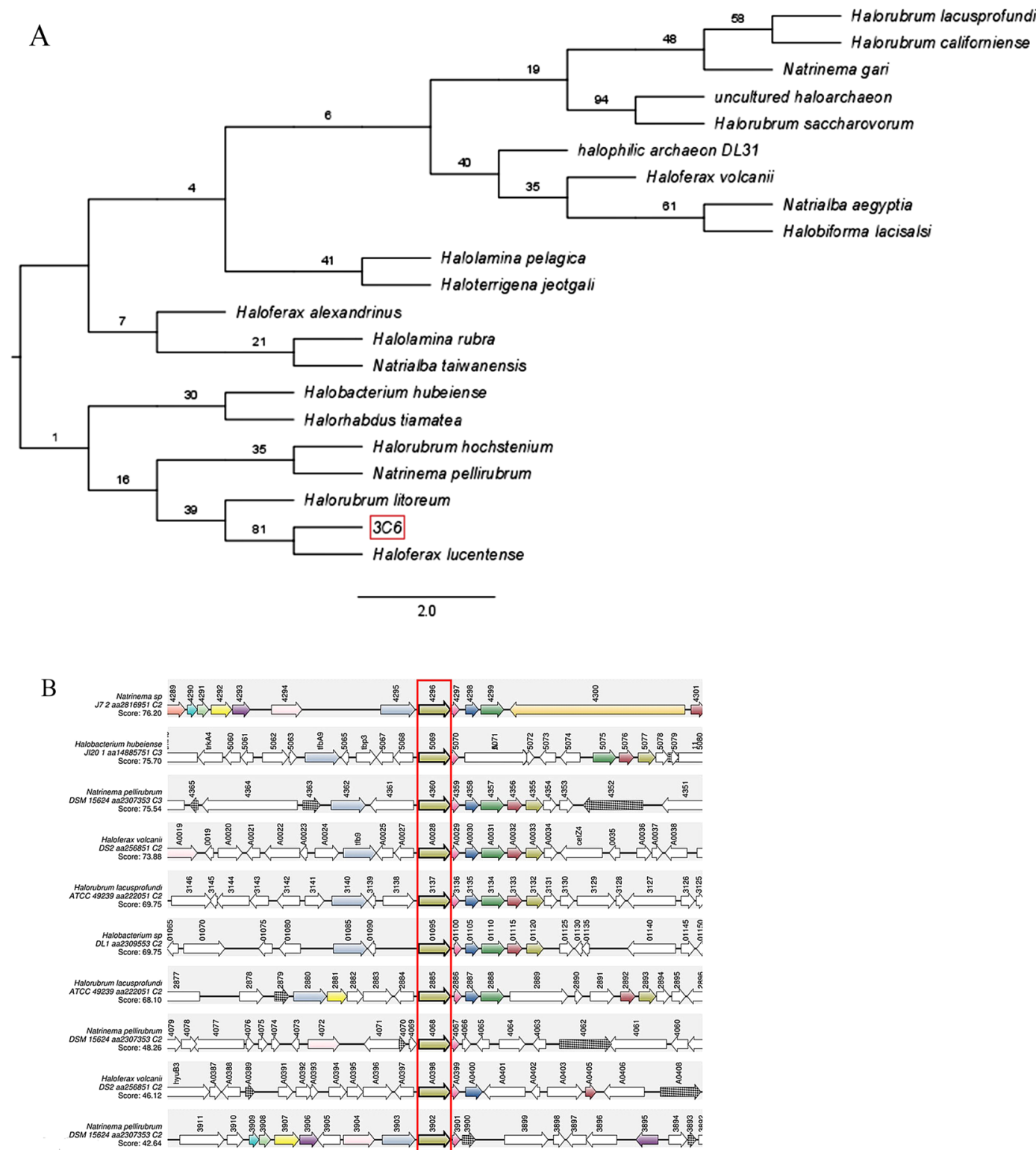

Figure 1. Identification of 3C6 clone (MBSP1): (A) Phylogenetic tree obtained from alignment by NeighbourJoining method highlighting hypothetical protein and highest similarity with Haloferax lucentense proteins. The 3C6 ORF is highlighted in the red box; (B) Map obtained from Absynte tool displaying the conservation of genes between the species of Archaea. Gene corresponding to 3C6 protein homologs is drawn in red box in centre of map.

$3 C 6$ protein expression. The 3C6 ORF was sub-cloned into the pHis-parallel1 expression vector, and cloning was confirmed by enzymatic digestion. The His-tagged protein was detected using InVision ${ }^{\mathrm{TM}}$ His-tag In-gel Stain (Invitrogen Corp., Carlsbad, CA, USA) in cell extracts. A protein band with an approximate molecular weight of $20 \mathrm{kDa}$ was detected after induction with IPTG, which was not observed in the empty pHis-parallell vector used as the negative control (Fig. 3A). Protein expression was also observed in cell-free supernatants at different induction times ( $4 \mathrm{~h}$ and $18 \mathrm{~h}$ ) and in the absence of IPTG, indicating that this protein was expressed. A recombinant protein band was visualised at a molecular weight of approximately $20 \mathrm{kDa}$ (Fig. 3B). Cell-free supernatants were precipitated with ammonium sulfate. After precipitation, a protein band was observed in 30-60\% fraction and subsequently purified with the HisTrap ${ }^{\mathrm{TM}}$ column (GE Healthcare, Chicago, IL, USA), showing a molecular weight around $20 \mathrm{kDa}$ (Fig. 3C). In addition, cell-free supernatants were subjected to surfactant precipitation with acid. A protein of approximately $20 \mathrm{kDa}$ was only detected in the sample from 3C6 cultures (Fig. 3D). We named this protein, "metagenomic biosurfactant protein 1 (MBSP1)."

MBSP1 biosurfactant activity. Biosurfactant activity was evaluated in cell-free supernatant, purified protein, and surfactant obtained by acid precipitation from bacteria cultures. After induction with IPTG, it was possible to observe the production of emulsion (Fig. 4A). Using cell-free supernatant, emulsification indices were 


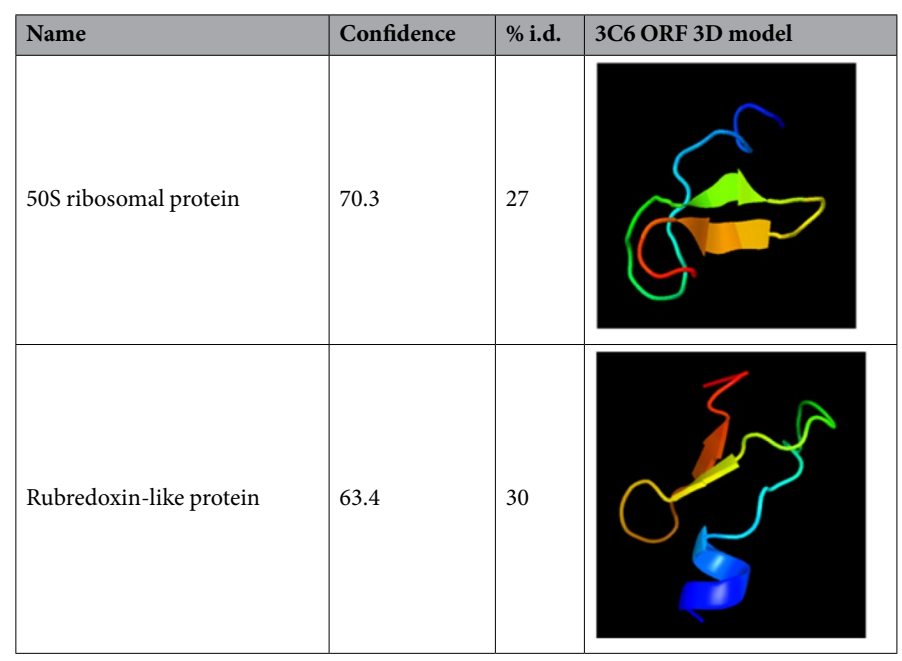

Table 1. Data obtained from PHYRE2 showed very low (non-statistical) structural similarity with ribosomal and rubredoxin-like proteins.

3C6

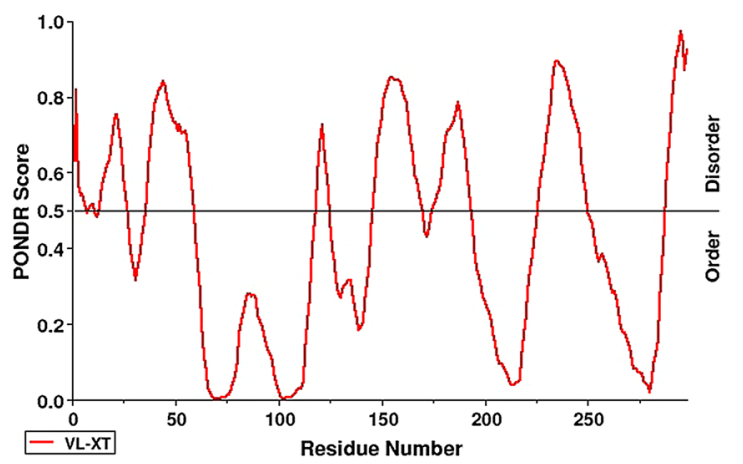

Figure 2. Prediction of intrinsic disorder by PONDR tool. The predicted degree of disorder tendency (scale $0-1$; cut-off 0.5 ) is charted over the amino acid positions within 3C6 ORF (MBSP1). The prediction tool indicates a mostly disordered protein structure. Red bars at the top of the diagram indicate the positions of disordered prediction in the structure.

obtained for different substrates. All hydrocarbons tested served as substrates for emulsification, except diesel. Emulsification indices were better in toluene and xylene (56,7\% and 51,9\%, respectively), followed by hexadecane and hexane (both 49\%). Compared with the positive control (1\% SDS), only kerosene showed a statistical difference (Fig. 4B). The pHis-parallell empty vector did not show positive emulsification results for any tested sources.

Emulsification was also observed with purified protein and the biosurfactant obtained via acid precipitation (data not shown). The protein nature of the surfactant was confirmed by treatment of the cell-free supernatant with proteinase $\mathrm{K}$ since no emulsification was observed (Fig. 4C).

MBSP1 presented positive results for drop collapse (Fig. 5A) and oil dispersion assays (Fig. 5B). Furthermore, it significantly reduced tension interfacial against petroleum $(p<0.05)$, similar to synthetic surfactant SDS $1 \%$. MBSP1 presented a median value of $6 \mathrm{~N} / \mathrm{m}$ and synthetic surfactant SDS $1 \%$ showed an average of $2.5 \mathrm{~N} / \mathrm{m}$ for interfacial tension, whereas water presented an average value of $35 \mathrm{~N} / \mathrm{m}$ (Fig. $5 \mathrm{C}$ ).

Stability of biosurfactant. The results showed that biosurfactant activity is stable in a wide range of salt concentrations and $\mathrm{pH}$ (Fig. 6A,B, respectively). Furthermore, an increase in the emulsification index was observed at higher salt concentrations. The biosurfactant was also tested in the presence of lipase and protease. The emulsification was not significantly affected by lipase treatment (Fig. 6C). However, no emulsifying activity was observed after the treatment of MBSP1 with proteinase K (Supplementary Fig. S3A). In addition, the emulsion was stable at high temperatures, since it was heated to $100^{\circ} \mathrm{C}$ and little change was observed (Supplementary Fig. S3B).

Hydrocarbons degradation potential. To assess the hydrocarbon assimilation potential, the microbial growth behaviours of $E$. coli Rosetta ${ }^{\mathrm{TM}}$ (DE3) strain cells carrying MBSP1 clone and the empty pHis-parallel1 expression vector in $\mathrm{BH}$ cultures containing $1 \%$ crude oil were evaluated. The assay was monitored for $7 \mathrm{~d}$, and both strains demonstrated the ability to grow in the conditions used. The pHis-parallell empty vector and the clone 
A

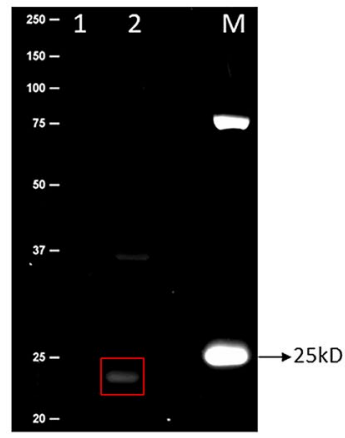

C

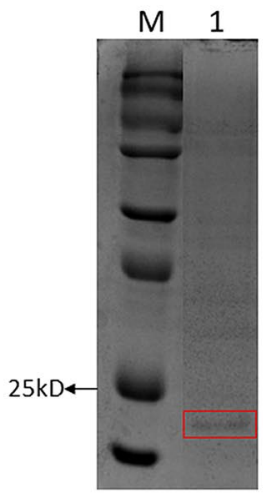

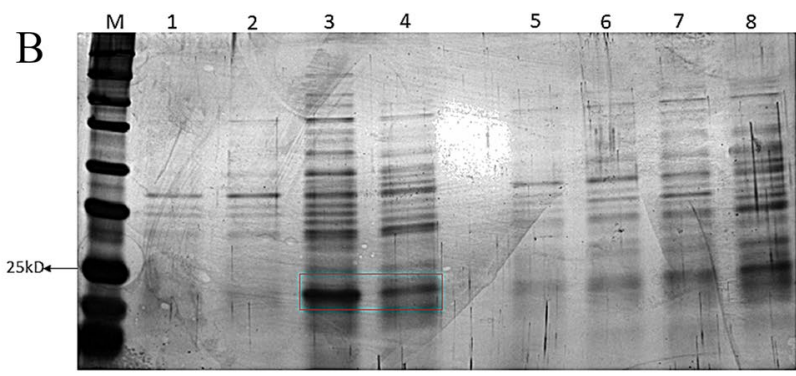

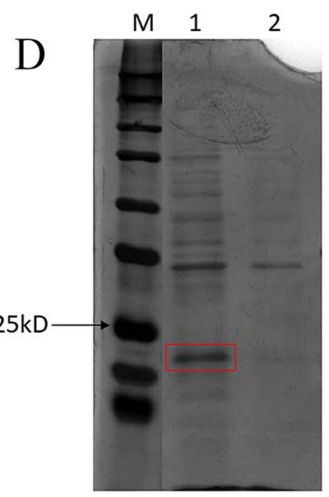

Figure 3. MBSP1 expression: (A) Detection of His tagged protein in cell extract using InVision ${ }^{\mathrm{TM}}$ His-tag In-gel Stain in polyacrylamide gel electrophoresis (SDS-PAGE). M- Kaleidoscope molecular weight marker of $250 \mathrm{kDa}$ (Bio-Rad, Hercules, CA, USA); 1- pHis-parallel1 (negative control). 2- MBSP1 protein (uncropped original picture); (B) Analysis of proteins in cell-free supernatant extract using polyacrylamide gel electrophoresis (SDS-PAGE) at $37^{\circ} \mathrm{C}$ with different induction times. M - Kaleidoscope molecular weight marker of $250 \mathrm{kDa}$ (Bio-Rad, Hercules, CA, USA) 1- MBSP1 clone non-induced. 2- MBSP1 clone induced at 4h. 3- MBSP1 clone induced at $18 \mathrm{~h} .4-\mathrm{MBSP} 1$ without IPTG at $18 \mathrm{~h}$. 5- pHis-parallel1 non-induced. 6- pHis-parallel1 induced for 4h. 7- pHis-parallel1 induced at $18 \mathrm{~h}$. 8- Non-induced pHis-parallel1 at $18 \mathrm{~h}$ (uncropped original picture); (C) Protein purified from cell-free supernatant using HisTrap column after ammonium sulfate precipitation with approximate molecular weight of $20 \mathrm{kDa}$, using polyacrylamide gel electrophoresis (SDS-PAGE). M- Kaleidoscope molecular weight marker of $250 \mathrm{kDa}$ (Bio-Rad, Hercules, CA, USA). 1- Purified protein (cropped figure, original gel is shown in Supplementary Fig. S4); (D) Proteins after acid precipitation with ammonium sulfate in SDSPAGE. M- Kaleidoscope molecular weight marker of $250 \mathrm{kDa}$ (Bio-Rad, Hercules, CA, USA). 1- Supernatant free of cells carrying MBSP1 after acid precipitation. 2- Supernatant free of cells transformed with pHis-parallel1 (negative control) after acid precipitation (cropped figure, original gel is shown in Supplementary Fig. S5).

MBSP1 displayed positive results for the degradation of a wide range of aliphatic hydrocarbons (Fig. 7). The most efficient alkane and isoprenoids (pristane and phytane) degradation occurred for the MBSP1 clone (above 80\%).

In contrast, the mineralisation of alkanes with C13-C32 demonstrated a decreased metabolic capacity (around $50 \%$ ) by cells transformed with pHis-parallel1. This strain also reached the lowest degradation percentages for the C7, pristane and phytane chains (below 15\%).

\section{Discussion}

The MBSP1 sequence showed a high similarity to hypothetical proteins $\mathrm{s}^{25,26}$ of the family Halobacteriaceae, some being identified as biosurfactant-producing species ${ }^{27}$. Bootstrap analysis demonstrated that the MBSP1 sequence was more comparable to $H$. lucentense. H. lucentense grows in a wide range of salinities ( $10 \%$ to $30 \%)$, and at a temperature and $\mathrm{pH}$ of $37^{\circ} \mathrm{C}$ and 7.5 , respectively ${ }^{28}$. This species can consume hydrocarbons such as crude oil, $\mathrm{n}$-octadecane, and phenanthren $\mathrm{e}^{29}$, but there are no reports on the production of biosurfactants by $H$. lucentense. However, other species of the genus Haloferax were described as biosurfactant producers.

Djeridi et al..$^{30}$ demonstrated that Haloferax sp. MSNC14 consumes different hydrocarbons and produces biosurfactant. However, the chemical nature of this biosurfactant was not identified. In addition, other species of Halobacterium were described as biosurfactant producers. Analysing the chromatographic behaviour of surfactants obtained from Halovivax (strain A21) and Haloarcula (strain D21), Kebbouche-Gana et al. ${ }^{27}$ revealed glycoproteins as the probable surfactant produced by D21, while A21 produced peptidoglycolipids (e.g., glycoprotein, glycolipid, or lipopeptide). Despite these descriptions of biosurfactant production in Halobacterium, the genes and pathways involved in the biosurfactant syntheses remain unknown. Therefore, in this study we described the first gene in the Archaea domain capable of surfactant production. 
A

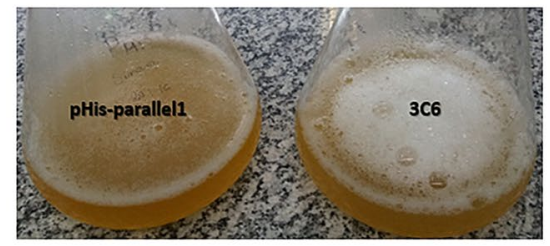

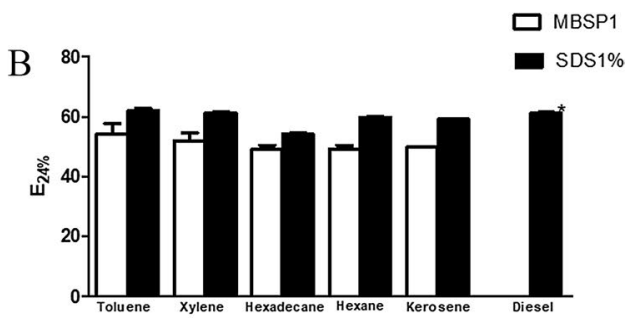

$\mathrm{C}$

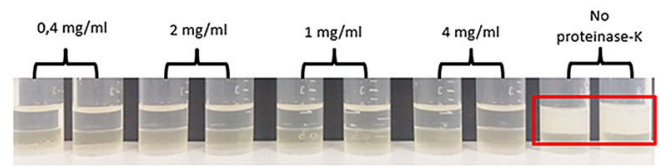

Figure 4. Bacterial culture of clone MBSP1 and empty vector pHis-parallel1 after IPTG induction and emulsification assay with different hydrocarbon sources. (A) Emulsion observed in culture containing MBSP1 after induction with IPTG; (B) Emulsification index (E24\%) showing similarity between MBSP1 and positive control 1\% SDS, using different hydrocarbon sources. Statistical difference was only observed in relation to diesel emulsification $(* p<0.05)$; (C) Supernatant containing MBSP1 treated with different concentrations of proteinase $\mathrm{K}(0.4,2,1,4 \mathrm{mg} / \mathrm{ml})$. In the control, no proteinase $\mathrm{K}$ was added, and emulsifying activity was maintained.

A

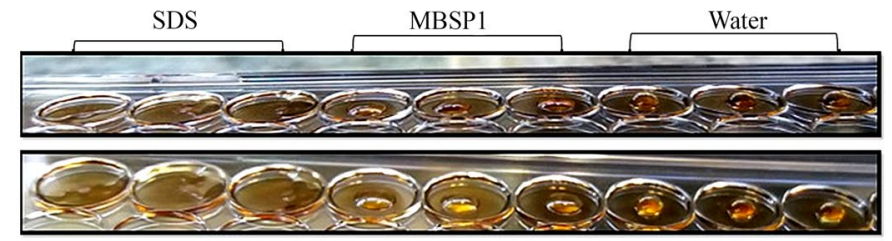

$\mathrm{B}$

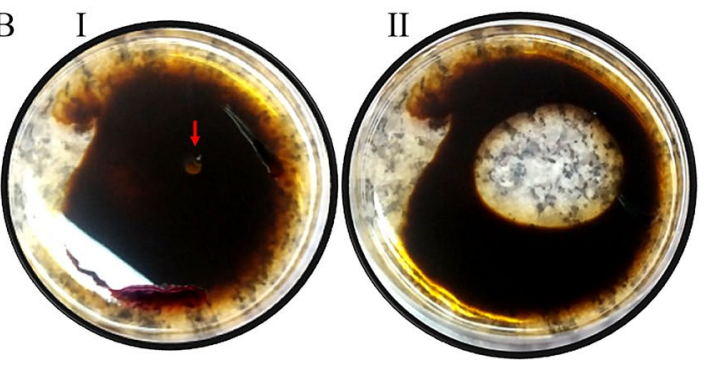

$\mathrm{C}$

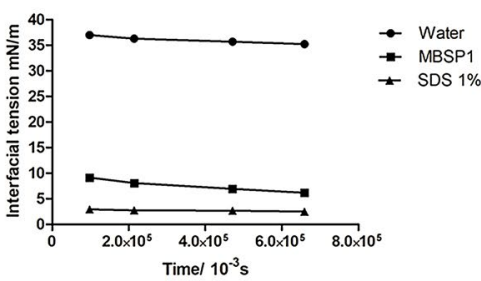

Figure 5. Biosurfactant activity of MBSP1 obtained by acid precipitation: (A) Drop collapse: a triplicate test evidencing collapsed drop in oil of both SDS positive control and biosurfactant. The water kept the formation of drops intact. (B) Oil dispersion test: I- MBSP1 added to plate (red arrow); II-Dispersion oil forming a halo caused by presence of MBSP1. (C) Interfacial tension. Mean values of interfacial tension of water, MBSP1 and synthetic surfactant SDS $1 \%$ against petroleum.

Additionally, PredictProtein software results indicated structural homology of MSBP1 with rubredoxin-like protein, but with low confidence values. Rubredoxin is a small protein with an active iron-sulphur site that is involved in the oxidation of alkanes in bacteria. Metabolic pathways were best characterised in Pseudomonas putida (Oleovorans) $\mathrm{GPO}^{31}$, and is capable of oxidising C5 to C12 alkanes to 1-alkanols. Smits et al. reported that the alkane hydroxylase system is composed of 3 components: alkane hydroxylase (AlkB), rubredoxin (AlkG), and rubredoxin reductase $(\text { AlkT })^{32}$.

The physicochemical properties of the amino acid sequence revealed a transmembrane helix located at the $95^{\text {th }}$ residue to the $112^{\text {th }}$, with a size of 18 amino acid residues-long.

Surfactin, for example, forms ion-conducting channels in bacterial lipid membranes, akin to that of detergents $^{33}$. Surfactin, as one of the most effective biosurfactants, is capable of destabilizing membranes that disrupt its integrity and permeability by forming pores $^{34}$.

The prediction of MBSP1 subcellular localisation, considering the Archaea domain, resulted in secretion ( $100 \%$ confidence), with the MBSP1 protein being recovered in the supernatant. This is an interesting result since no canonical localisation domain was found in this sequence for expression in E. coli.

MBSP1 protein was detected with an approximate molecular weight of $20 \mathrm{kDa}$ after induction with IPTG. Protein expression was also observed in the cell-free supernatant at different induction times ( $4 \mathrm{~h}$ and $18 \mathrm{~h}$ ) and in the absence of IPTG, indicating that this protein is secreted. The molecular weight observed was different from 
A

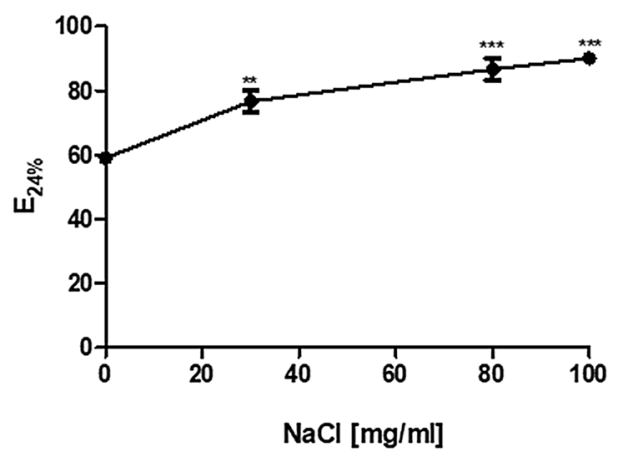

$\mathrm{C}$

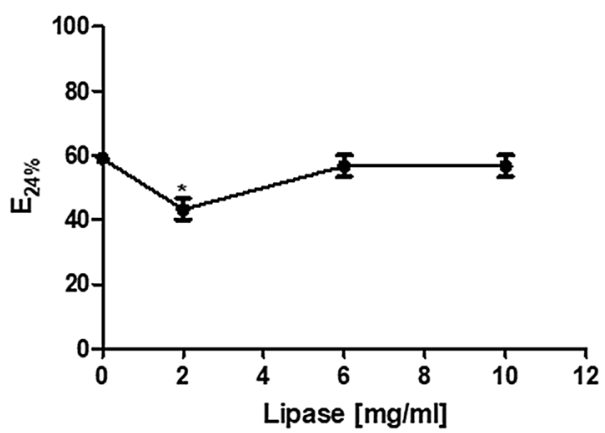

B

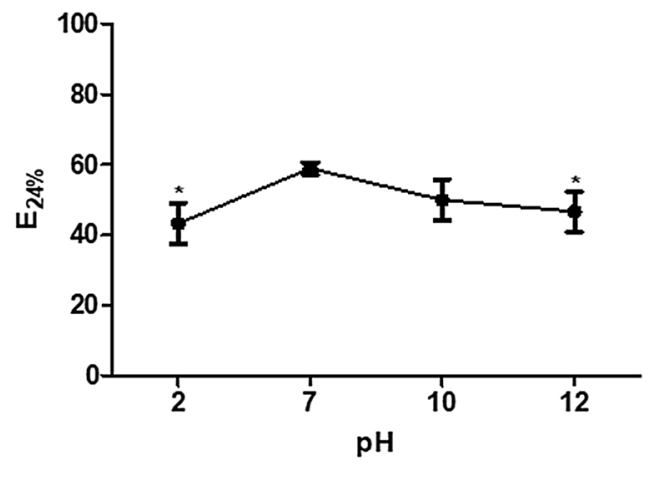

Figure 6. Stability of MBSP1 obtained by acid precipitation measured by emulsification test using kerosene as a substrate. (A) MBSP1 exposed to different concentrations of salt. (B) Treatment with different $\mathrm{pH}$. (C) Treatment with lipase. Data were analysed using two-way ANOVA followed by Dunnett's test $(* \mathrm{p}<0.05$ to $* * * \mathrm{p}<0.0001)$.

the expected weight of approximately $32 \mathrm{kDa}$. This can be explained by the cleavage of a possible signal peptide (yet unknown). Such cleavage may lead to the release of the protein to the extracellular medium or by the disordered regions of the protein, which may be causing a differential migration in polyacrylamide gel ${ }^{35}$. Moreover, the structure predicted protein revealed several disordered regions.

Biosurfactant activity was positive in cell-free supernatants, purified protein, and surfactant obtained by acid precipitation from MBSP1 clone cultures. Therefore, MBSP1 is a potential candidate for use in a variety of biotechnological and industrial applications. According to Gudiña and collaborators, a broad-spectrum of emulsifying activity is essential for the use of a bioemulsifier in industrial processes, which includes different mixtures of hydrophobic compounds ${ }^{36}$.

In general, for an emulsion to be considered effective, the emulsification index should be higher than $40 \%{ }^{37}$. MBSP1 presented satisfactory results $(>50 \%)$, and the kerosene emulsion was stable for more than one year. Biosurfactants secreted to the extracellular environment emulsify oily compounds, increase their bioavailability, accelerate their metabolism, and mediate ecological interactions with other organisms by quorum sense regulation $^{38}$. Interestingly, MBSP1 is an Archaea protein secreted by the Escherichia coli host strain. Further elucidation of this mechanism may lead to the production of other recombinant proteins that can be secreted by E. coli. This may facilitate the purification of more proteins with biotechnological applications.

MBSP1 differs from most biosurfactants such as glycolipids, glycopeptides, lipopeptides, and lipopolysaccharides $^{6}$ since it is active as a single peptide. MBSP1 has surfactant functions: for example, stabilising an emulsion and reducing interfacial tension, which may be useful for biotechnological applications. The large-scale production of biosurfactants remains a challenge due to several limitations, which include dependence on complex genetic systems as operons, non-ribosomal peptide synthetases, and/or multiproteic assembly complexes. Furthermore, the large-scale biosurfactant production also depends on raw materials and adequate substrates; the availability of surfactant-producing microorganisms; adequate industrial fermenters; purification processes; biosurfactant properties; and production yields ${ }^{7,8}$. The characteristics presented by MBSP1 point toward the potential of large-scale biosurfactant production, thus overcoming existing limitations for the biosurfactants described so far.

The stability of biosurfactants was tested at high temperatures, under proteolytic conditions, and under different concentrations of salt and $\mathrm{pH}$. A small number of bacterial species have been described as active biosurfactant producers under extreme conditions ${ }^{39}$. To thrive in harsh environments, microorganisms produce enzymes and metabolites that are functional under the prevailing conditions of their surroundings. MBSP1 remains active over 
A
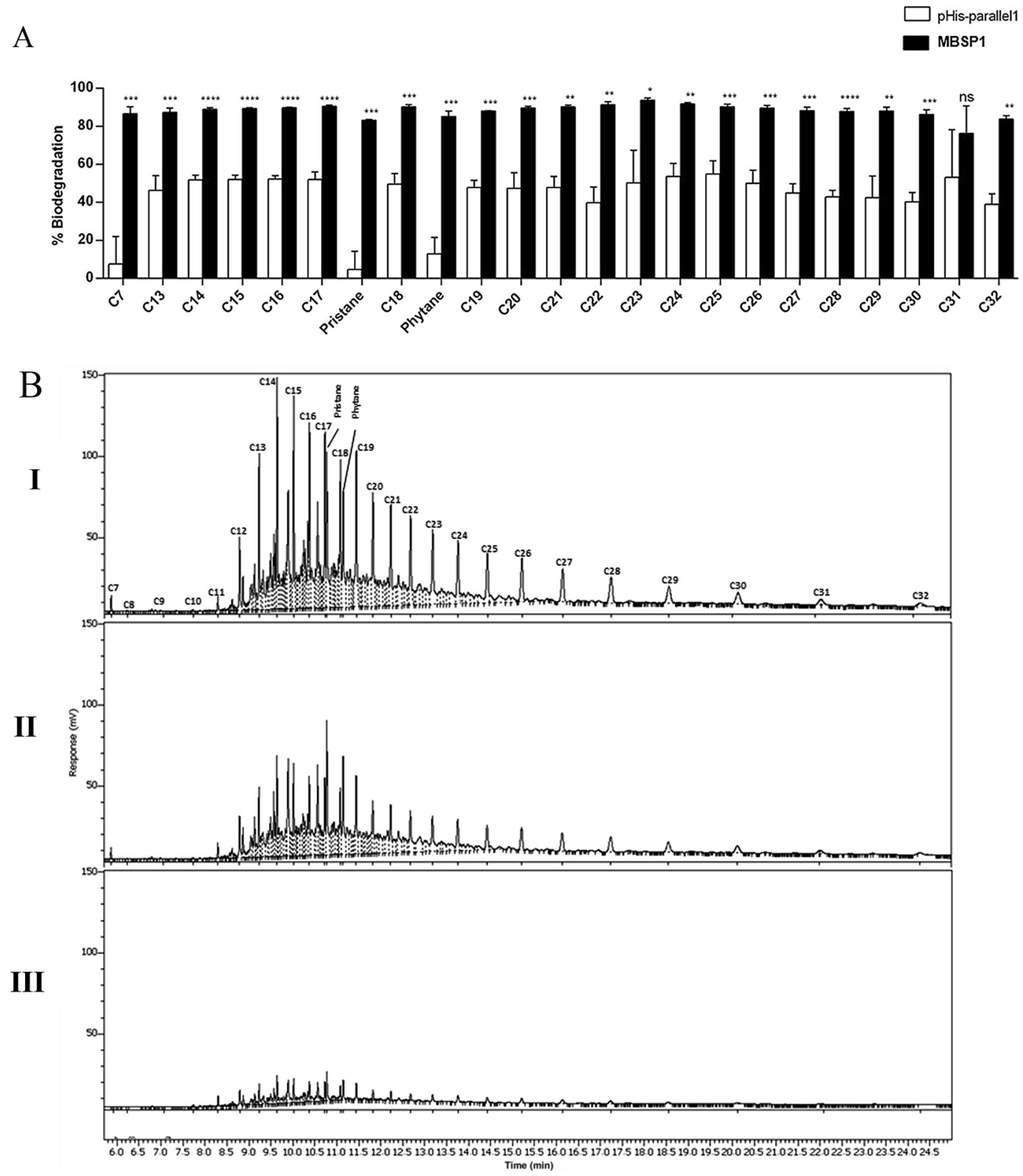

Figure 7. Aliphatic hydrocarbons degradation by MBPS1 clone and empty pHis-parallel1. (A) Comparison of percentage of aliphatic hydrocarbon biodegradation between MBSP1 and empty vector pHis-parallel1. Microorganisms were incubated in sterile $\mathrm{BH}$ medium contaminated with $1 \%$ (wt./v) aliphatic hydrocarbons (C7 to C32, pristane and phytane) as the source of carbon and energy, for $7 \mathrm{~d}$ at $30^{\circ} \mathrm{C}$ and $200 \times \mathrm{g}$. Data are shown as the mean \pm RSD (\%) from three biological replicates. Normalised data based on the negative control; unpaired Student's t-test was performed $(* p<0.05$ to $* * * * p<0.00001)$. (B) Aliphatic hydrocarbon degradation by I- Negative control (BH + crude petroleum); II- Empty pHis-parallel1; III-MBSP1.

a wide range of temperatures, $\mathrm{pH}$, and salinity, which may contribute to its adaptation to extreme environmental conditions. MBSP1 was identified in a metagenomic library derived from an environment without oil contamination, differing from most biosurfactant prospective studies, which are generally performed in marine or terrestrial environments with a history of oil contamination.

When compared to synthetic surfactants, biosurfactants are generally more effective at a wide range of salinity and temperature. Temperature and saline concentration are key parameters that affect emulsifying activity in advanced oil recovery processes. The stability of MBSP1 at different salt concentrations is in accordance with soil characteristics from which this gene was identified. Thermostability is a critical property for various industrial applications of biosurfactants. Furthermore, salinity influences dispersant activity, i.e., higher salinities tend to favour the action of dispersants, suggesting that in real situations of oil spills in marine environments, dispersants would perform even better than what was observed ${ }^{40}$. 


\begin{tabular}{|c|c|}
\hline Strains & Genotype/Description \\
\hline $\mathrm{DH} 10 \mathrm{~B}\left(\mathrm{recA}^{-}\right)$ & $\begin{array}{l}\mathrm{F} \text {-endA1 recA1 galE15 galK16 nupGrpsL } \Delta \text { lacX74 } \Phi 80 \mathrm{lacZ} \Delta \mathrm{M} 15 \text { araD139 } \\
\Delta \text { (ara,leu)7697 mcrA } \Delta \text { (mrr-hsdRMS-mcrBC) } \lambda-\end{array}$ \\
\hline $\mathrm{DH} 5 \alpha$ & $\begin{array}{l}\mathrm{F}-\text { } 980 \text { lacZ } \Delta \mathrm{M} 15 \Delta(\text { lacZYA-argF) U169 recA1 endA1 hsdR17 (rK-, mK+) } \\
\text { phoA sup } 44 \lambda-\text { thi-1 gyrA96 relA1 }\end{array}$ \\
\hline Rosetta $^{\mathrm{TM}}(\mathrm{DE} 3)$ & $\begin{array}{l}\text { E. coli strain used for protein expression; } \mathrm{F}^{-} o m p \mathrm{~T} \text { hsdS } \mathrm{B}_{\mathrm{B}}\left(\mathrm{r}_{\mathrm{B}}{ }^{-} \mathrm{m}_{\mathrm{B}}{ }^{-}\right) \text {gal-dcm } \\
(\mathrm{DE} 3) \mathrm{pRARE}\left(\mathrm{Cam}^{\mathrm{R}}\right)\end{array}$ \\
\hline \multicolumn{2}{|l|}{ Plasmids } \\
\hline $\mathrm{pBC} \mathrm{SK}$ & Cloning vector, $\mathrm{Cam}^{\mathrm{r}}$ \\
\hline pCR-Blunt II-TOPO & Cloning vector, $\operatorname{Kan}^{\mathrm{r}}$ \\
\hline pHis-parallell & $\begin{array}{l}\text { Vector for in vitro expression with T7 promoter, adds GB1 solubility tag; IPTG } \\
\text { inducible; restriction enzyme cloning; Amp }\end{array}$ \\
\hline
\end{tabular}

Table 2. Strains and plasmids used in this study.

In addition, bacteria transformed with the empty vector pHis-parallell and clone MBSP1 presented degradability of aliphatic hydrocarbons. However, the results showed that the clone MBSP1 demonstrated an increase in degradation activity since a higher percentage of hydrocarbon degradation was observed. This increase may be attributed to the MBSP1 biosurfactant activity. In fact, Nievas et. al., described that the addition of biosurfactants caused an increase in the biodegradation of hydrocarbons through the mechanisms of mobilisation, solubilisation, or emulsification ${ }^{41}$. The increase of the biodegradation (above 60\%) of the phytane and pristane compounds by MBSP1 clone reinforces this hypothesis because they are isoprenoid alkanes, which are extremely resistant to biodegradation due to the presence of molecular branching ${ }^{42}$.

In general, 20 to $40 \%$ of the sequences generated in metagenome projects are classified as hypothetical genes, due to the lack of similarity with known genes. In this context, functional screening has been useful for the identification of these new genes. Here, we identified and characterised a hypothetical protein that showed surfactant properties, being the first of its kind described in Archaea or Bacteria domains. We described a single gene that codifies a protein with interesting surfactant properties that can be produced in host cells such as E. coli without dependence on substrate, which reduces some limitations of large-scale production of biosurfactants, indicating its potential for the development of biotechnological products.

\section{Material and Methods}

Construction of metagenomic library and functional screening. Soil samples were collected from Jundiaí Riverbanks (Natal, Brazil), which were characterised by high salinity (description of collecting point is in Supplementary Table S1). An overview of the steps and procedures used in this study are provided in the Supplementary Fig. S6. Collection was performed using sterile tubes and spatulas, where environmental DNA (eDNA) was extracted using the commercial FastDNA ${ }^{\mathrm{TM}}$ SPIN Kit for Soil (Qbiogene, Inc., Carlsbad, CA, USA) from $10 \mathrm{~g}$ of soil. DNA fragments $(1-3 \mathrm{kB})$, obtained by sonication were inserted into $\mathrm{pBC}$ phagemid vectors having E. coli (strain DH10B) as the host strain. Strains and plasmids used in this study are listed in Table 2. A functional screening was performed to detect the presence of genes with activity in oil degradation and biosurfactant production. For the oil degradation assay, $10 \mu \mathrm{L}$ of the culture from each clone was transferred to 96-well plates (with lid) containing $180 \mu \mathrm{L}$ of LB medium with $25 \mu \mathrm{g} / \mathrm{mL}$ chloramphenicol. After a drop of light Arabic oil was added, the test plate was incubated for $15 \mathrm{~d}$ at $30^{\circ} \mathrm{C}$. The oil aspect was observed daily. Clones showing oil degradation were replicated in 24-well plates (with lid) containing $1.8 \mathrm{~mL}$ of LB medium with $25 \mu \mathrm{g} / \mathrm{mL}$ chloramphenicol, and the oil degradation assay was repeated. Plasmid DNA extraction was performed from clones that presented positive degradation results. Each clone was retransformed into the DH10B strain, and the oil degradation assay was repeated for confirmation. The $\mathrm{DH} 10 \mathrm{~B}$ strain containing the empty plasmid was used as a negative control. Positive clones that showed confirmed degradation activity were tested for biosurfactant production. Tests performed were: drop collapse $^{43}$, emulsification assay ${ }^{44}$, and oil dispersion assay ${ }^{45}$. The clones with the best results were sequenced (11 clones in total) using DYEnamic ET Dye Terminator Cycle Sequencing Kit for MegaBACE ${ }^{\mathrm{TM}} 500$ (Amersham Biosciences Corp., Little Chalfont, UK) following manufacturer's instructions. In this study, we described the execution of functional assays with one ORF identified in one clone (named 3C6) that showed positive results for all tests.

ORF identification and sequence analysis. The predicted ORF sequences present in clone 3C6 were made using the ORF finder program, available online through the National Center for Biotechnology Information (NCBI) website (https://ww.ncbi.nlm.nih.gov/orffinder/) accessed in February 2017. The characterised nucleotide sequence in this study was deposited in the GenBank database under the Accession Number MK165391. Molecular weight and isoelectric point (pI) were predicted using the ExPASy Compute pI/Mw tool (http://web. expasy.org/compute_pi/). The obtained sequence was submitted to BLAST, and homologs were selected (https:// blast.ncbi.nlm.nih.gov/Blast.cgi) using the non-redundant (nr) protein database. Sequences of the predicted ORF and its homologs were aligned in the CLUSTAL Omega program (Conway Institute, UCD. Belfield, Dublin 4, Ireland ${ }^{46}$ and phylogenetic trees were generated by molecular evolutionary genetics analysis (MEGA) 7 software (Penn State University, University Park, PA, USA) ${ }^{47}$. Methods used to obtain trees were Neighbour-Joining (NJ), maximum likelihood, and maximum parsimony, all with 1000 bootstrap values. The amino acid sequence was submitted to the automatic online service, PredictProtein (PP) software (https://www.predictprotein.org/), and the protein structure prediction was submitted to the web-based service for protein structure prediction, Phyre2 software (http://www.sbg.bio.ic.ac.uk/phyre2/html/page.cgi?id = index). The identification of conserved synteny 


\begin{tabular}{|l|l|l|l|l|}
\hline Protein & Restriction Enzyme (Sequence $\mathbf{5}^{\prime}-\mathbf{3}^{\prime}$ ) & Oligonucleotides & MT $^{*}$ & Fragment size \\
\hline \multirow{2}{*}{ ORF3C6 } & Foward_BsaI GGTCTCCCATGAGTGATCAATATCT & $62,9^{\circ} \mathrm{C}$ & \multirow{2}{*}{897} \\
\cline { 2 - 4 } & pb Reverse_HindIII AAGCTTTTAAGTCGAGTCCTGACCC & $64,6^{\circ} \mathrm{C}$ & \\
\hline
\end{tabular}

Table 3. Sequence of oligonucleotides and parameters used for amplification of gene coding for ORF 3C6. $* \mathrm{MT}=$ Melting Temperature.

regions containing 3C6 orthologs was performed by Absynte (Archaeal and Bacterial Synteny Explorer), a web-based service designed to display local syntenies in completely sequenced prokaryotic chromosomes (http:// archaea.u-psud.fr/absynte/). The Predictor of Natural Disordered Regions (http://www.pondr.com/) was utilised for the amino acid sequence, which considers a residue as disordered if its value exceeds or matches a threshold of 0.5. Peptide 2.0 (https://www.peptide2.com/N_peptide_hydrophobicity_hydrophilicity.php) was performed for verifying the peptide's hydrophobicity.

Sub-cloning of metagenomic ORF. Specific primers were sequenced, containing restriction sites for the BsaI and HindIII enzymes added to their $5^{\prime}$ regions (Table 3 ). The amplicon was initially cloned into a pCR ${ }^{\circledR}-B_{\text {Bunt }}$ vector (Invitrogen Corp., Carlsbad, CA, USA) and transformed into E. coli (strain DH5 $\alpha$ ). Enzymatic digestion with EcoRI (Biolabs, Cambridge, MA, USA) was used for cloning confirmation. The ORF of interest was excised from the cloning vector with the two enzymes, BsaI and HindIII. Then, the ORF of interest was sub-cloned into the pHis-parallell expression vector previously linearised with $\mathrm{NcoI}$ and XhoI enzymes to generate sequence ends compatible with the $3 \mathrm{C}_{6} \mathrm{ORF}^{48}$. Ligation of inserts into the vector $(3 \mathrm{C} 6+$ pHis-paralle1) was obtained through heat-shock, which transformed the clone into the E. coli strain named Rosetta ${ }^{\mathrm{TM}}$ (DE3). Rosetta ${ }^{\mathrm{TM}}$ (DE3) was used as the heterologous expression system. The sub-cloned ORF was named MBSP1 (metagenomic biosurfactant protein 1).

Recombinant protein expression. Rosetta ${ }^{\mathrm{TM}}$ (DE3) competent cells carrying the MBSP1 clone and the empty pHis-parallel1 vector were grown in $400 \mathrm{~mL}$ lysogeny broth (LB) medium containing $100 \mu \mathrm{g} / \mathrm{mL}$ ampicillin and $34 \mu \mathrm{g} / \mathrm{mL}$ chloramphenicol at $37^{\circ} \mathrm{C}$. Cells were grown to $\mathrm{OD}_{600 \mathrm{~nm}}$ of approximately 0.45 . Protein expression was induced with $1 \mathrm{mM}$ isopropyl- $\beta$-D-1-thiogalactopyranoside (IPTG) for $18 \mathrm{~h}$ at $37^{\circ} \mathrm{C}$. The cell extract was collected by centrifugation at $15,000 \times \mathrm{g}$ for $20 \mathrm{~min}$ and resuspended in $1 \mathrm{X}$ PBS. Cell lysis was performed by adding lysis buffer $(0.5 \mathrm{M} \mathrm{NaCl} ; 10 \%$ Glycerol; $20 \mathrm{mM}$ Hepes, $\mathrm{pH} 7.5 ; 5 \mathrm{mM}$ Imidazole, $\mathrm{pH}$ 7.5; and $2 \mathrm{mM}$ $\beta$-mercaptoethanol), $1 \mathrm{mM}$ of the protease inhibitor phenylmethylsulfonyl fluoride (PMSF), $1 \mathrm{mg} / \mathrm{mL}$ lysozyme, $0.5 \%$ of $10 \%$ Triton X-100, and $150 \mathrm{U}$ of Novagen ${ }^{\mathrm{TM}}$ Benzonase $^{\circledR}$ Nuclease $(10 \mathrm{KU}-25 \mathrm{U} / \mu \mathrm{L})$ (FischerScientific, San Diego, CA, USA). The sample was kept on ice for $1 \mathrm{~h}$ and periodically inverted. At the end of this step, the sample was sonicated until loss of viscosity. Thereafter, each sample was centrifuged at $20,000 \times \mathrm{g}$ for $45 \mathrm{~min}$ at $4{ }^{\circ} \mathrm{C}$. The supernatant was collected in a new pre-frozen tube. Samples were then visualised by $12 \%$ polyacrylamide gel electrophoresis (SDS-PAGE).

Detection of His-tagged fusion protein was performed using InVision ${ }^{\mathrm{TM}}$ His-tag In-gel Stain (Invitrogen Corp., Carlsbad, CA, USA). This method is sensitive, highly specific, and allows for direct visualisation of bands of the His-tagged fusion protein on a polyacrylamide gel after electrophoresis. $\mathrm{Ni}^{2+}$ conjugated fluorescent dye was utilised, which binds with a high affinity to histidine residues providing a clear and specific visualisation of the His-tagged protein. After electrophoresis, proteins were fixed onto the gel, followed by staining according to the manufacturer's instructions. His-tagged protein was visualised in the ChemiDoc ${ }^{\mathrm{TM}} \mathrm{MP}$ System (Bio-Rad, Hercules, CA, USA).

Purification of the recombinant protein was performed by affinity chromatography using the HisTrap ${ }^{\mathrm{TM}}$ column (GE Healthcare, Chicago, IL, USA). In total, $20 \mathrm{~mL}$ of Buffer A (800 mM NaCl; $20 \mathrm{mM}$ Tris-HCl, pH 8.0; $5 \mathrm{mM}$ Imidazole; $2 \mathrm{mM} \beta$-Mercaptoethanol; and $10 \%$ Glycerol) was used to equilibrate the column. For binding the target protein to the column, the entire volume of protein extract was passed through the column. Column lavage was performed using $50 \mathrm{~mL}$ Buffer A and 10\% Buffer B $(800 \mathrm{mM} \mathrm{NaCl} ; 20 \mathrm{mM}$ Tris- $\mathrm{HCl}, \mathrm{pH} 8.0 ; 300 \mathrm{mM}$ Imidazole; $2 \mathrm{mM} 3$-Mercaptoethanol; and $10 \%$ Glycerol). In total, $100 \%$ of Buffer B was used to elute the protein. Finally, all steps of the purification process were applied to a $12 \%$ acrylamide gel.

The biosurfactant produced by clone MBSP1 was partially purified by acid precipitation according to the method described by Vater et al ${ }^{49}$ with minor modifications. $50 \mathrm{~mL}$ aliquots of bacterial culture were centrifuged in $50 \mathrm{~mL}$ conical tubes at $20,000 \times \mathrm{g}$ for $20 \mathrm{~min}$ at $4^{\circ} \mathrm{C}$ for the removal of cells. Then, the $\mathrm{pH}$ of the supernatant was adjusted to 2.0 by the addition of $6.0 \mathrm{~mol} . \mathrm{L}^{-1}$ of $\mathrm{HCl}$ and maintained at $4{ }^{\circ} \mathrm{C}$ for $18 \mathrm{~h}$. The sample was centrifuged at $20,000 \times \mathrm{g}$ for $20 \mathrm{~min}$; thereby, the supernatant was discarded, and the biosurfactant was eluted in water. The addition of $1.0 \mathrm{~mol} . \mathrm{L}^{-1} \mathrm{NaOH}$ enhanced solubilisation.

Salting-out was performed for precipitation of the biosurfactant by adding ammonium sulfate. Three different fractions were tested: $0-30 \%, 30-60 \%$, and $60-90 \%$. Initially, $8.8 \mathrm{~g}$ of ammonium sulfate was added to the cell-free supernatant for fraction $0-30 \%$, and left overnight for precipitation. The sample was centrifuged at $20,000 \times \mathrm{g}$ for $20 \mathrm{~min}$ at $4{ }^{\circ} \mathrm{C}$, and the precipitate was resuspended in water. Eluted proteins were dialysed in $200 \mathrm{~mL}$ of buffer $\left(800 \mathrm{mM} \mathrm{NaCl} ; 20 \mathrm{mM}\right.$ Tris-HCl, $\mathrm{pH} 8.0 ; 5 \mathrm{mM}$ Imidazole; $2 \mathrm{mM} \beta$-Mercaptoethanol; and $10 \%$ Glycerol) at $4{ }^{\circ} \mathrm{C}$ for $16 \mathrm{~h}$ in SnakeSkin ${ }^{\mathrm{TM}}$ Dialysis Tubing (68100) (ThermoScientific, San Diego, CA, USA) of $10 \mathrm{kDa}$ molecular weight cut-off (MWCO). This procedure was repeated for the remaining fractions where only the amount of ammonium sulfate added was changed. For the fraction 30-60\%, $9.9 \mathrm{~g}$ was added, and for the fraction $60-90 \%$, $11.35 \mathrm{~g}$ of ammonium sulfate was added. The recombinant protein obtained was purified as previously described and observed on a $12 \%$ polyacrylamide denaturing gel (SDS-PAGE). 
Biosurfactant activity. The emulsification index $\left(\mathrm{E}_{24 \%}\right)$ of culture samples were determined by adding $2 \mathrm{~mL}$ of a hydrocarbon (kerosene, diesel, hexane, hexadecane, toluene, and xylene) to the same amount of supernatant (of clone MBSP1 and empty vector). Mixing was accomplished by vortex for $2 \mathrm{~min}$, followed by a $24 \mathrm{~h}$ rest period. $\mathrm{E}_{24 \%}$ was determined as the height of the emulsion layer divided by the total height and multiplied by $100^{44}$. The assay was performed in duplicates.

Cell-free supernatants were incubated with different concentrations of proteinase $\mathrm{K}(5,10$, and $20 \mathrm{mg} / \mathrm{mL})$ at $37^{\circ} \mathrm{C}$ for $10 \mathrm{~min}$. Then, an emulsification assay was performed using kerosene as the hydrophobic substrate.

The oil dispersion test, the drop collapse test, and evaluation of interfacial tension were performed with the precipitated biosurfactant. For the oil dispersion test, $1 \mathrm{~mL}$ of oil was added to the surface of $40 \mathrm{~mL}$ of distilled water in a Petri dish, forming a thin layer of oil. Then, $10 \mu \mathrm{L}$ of biosurfactant was gently added at the centre of the oil layer ${ }^{50}$. The drop collapse test described by Jain et al., was performed on the cover of a 96 -well plate ${ }^{43}$. To the halos were added $2 \mu \mathrm{L}$ of oil, which was allowed to stand for $24 \mathrm{~h}$ at $25^{\circ} \mathrm{C}$ for stabilisation. On the following day, $5 \mu \mathrm{L}$ of biosurfactant was added, and the drop form was inspected after $1 \mathrm{~min}$. The assay was performed in triplicates. SDS (20\%) and water were used as positive and negative controls, respectively. Interfacial tension was evaluated by the Drop Volume Tensiometer, model DVT50 (Kruss Scientific, Hamburg, Germany) using the rising drop method, in which the force between the liquid containing surfactant (bulk phase) and oil droplet formed in the dispense phase was evaluated. The test was performed using $15 \mathrm{~mL}$ of biosurfactant in the bulk phase and petroleum in the dispense phase. The assay was performed according to the manufacturer's instructions. SDS (1\%) and water were used as positive and negative controls, respectively.

Stability of biosurfactant. The stability of biosurfactant obtained by acid precipitation was tested to determine its emulsification ability (using kerosene as the hydrocarbon source) after several treatments. All assays were performed in a $2 \mathrm{~mL}$ microtube. For the thermostability test, the biosurfactant was subjected to a temperature of $100^{\circ} \mathrm{C}$ for $1 \mathrm{~h}$. For the halo-stability study, different concentrations of sodium chloride $(30,80$, and $100 \mathrm{mg} / \mathrm{ml})$ were added to the biosurfactant. The biosurfactant was subjected to different $\mathrm{pH}$ conditions $(2,7,10$, and 12$)$ by the addition of hydrochloric acid and sodium hydroxide. To test biosurfactant proteolytic resistance, $0.1,0.2$, and $0.3 \mathrm{mg} / \mathrm{ml}$ of proteinase $\mathrm{K}$ were added. To analyse its lipase resistance, $2.0,6.0,7.0$, and $10 \mathrm{mg} / \mathrm{ml}$ of this enzyme were added.

Petroleum hydrocarbons degradation analysis. E. coli strain Rosetta ${ }^{\mathrm{TM}}$ (DE3) cells carrying MBPS1 and empty pHis-parallel1 were evaluated for their biodegradation ability using crude petroleum from Brazil with predominant concentrations of aliphatic hydrocarbons (C7-C32). The microorganisms were pre-cultured in $50 \mathrm{~mL}$ lysogeny broth (LB) medium containing $100 \mu \mathrm{g} / \mathrm{mL}$ ampicillin and $34 \mu \mathrm{g} / \mathrm{mL}$ chloramphenicol at $37^{\circ} \mathrm{C}$. Protein expression was induced with $1 \mathrm{mM} \mathrm{IPTG}$ for $18 \mathrm{~h}$ at $37^{\circ} \mathrm{C}$. The cells were centrifuged $(15,000 \times \mathrm{g}, 20 \mathrm{~min}$, $\left.4{ }^{\circ} \mathrm{C}\right)$, washed twice, and suspended $\left(0.1 \mathrm{OD}_{600 \mathrm{~nm}}\right)$ with sterile Bushnell-Haas $(\mathrm{BH})$ medium (Sigma-Aldrich Corp., St. Louis, MO, USA). The cultures were inoculated in $20 \mathrm{~mL}$ of sterile BH medium supplemented with crude petroleum $(1 \%) \mathrm{wt} . / \mathrm{v}$ and incubated on a rotatory shaker $(180 \times \mathrm{g})$ for $7 \mathrm{~d}$ at $30^{\circ} \mathrm{C}$. Biodegradation negative controls were performed with no addition of microbial inoculum.

After $7 \mathrm{~d}$ of incubation, petroleum hydrocarbon fractions were subjected to a liquid-liquid extraction process. The extract was concentrated in a rotary evaporator and subjected to preparative liquid chromatography to clean up the aliphatic fraction (F1). The separation of F1 was performed in glass columns, where silica gel $60\left(\mathrm{SiO}_{2}\right)$, aluminium oxide $90\left(\mathrm{Al}_{2} \mathrm{O}_{3}\right)$, and sulphate chloride $\left(\mathrm{Na}_{2} \mathrm{SO}_{4}\right)$ were used as the stationary phase; $\mathrm{n}$-hexane comprised the mobile phase $\mathrm{e}^{51,52}$. The identification of the constituents of the aliphatic fraction was based on the respective retention times of analytical standards ${ }^{51}$. The aliphatic hydrocarbons were analysed by Gas Chromatography with Flame Ionization Detector GC-FID on a Clarus ${ }^{\circledR} 600$ Chromatograph Adapter (PerkinElmer, Inc., Waltham, MA, USA $)^{53}$. Quantitative analyses were performed using the modified external standardisation method $^{54-56}$. Biodegradation percentage was calculated based on the following Eq. (1).

$$
B_{p}=\left[\left(C_{i}-C_{f}\right) / C_{i}\right] \times 100
$$

Where Bp refers to the biodegradation percentage at the end of incubation time; $C_{i}$ represents the amount of contaminant at the start of incubation; and $C_{f}$ represents the amount of contaminant at the end of incubation ${ }^{57}$.

Statistical analysis. Statistical comparisons for the emulsification index between MBPS1 and positive control 1\% SDS was done using unpaired t-test with Welch's correction. For multiple comparisons between treatments, ANOVA followed by Dunnett's test were used for the parametric ANOVA test applied interfacial tension assessment. For aliphatic hydrocarbons degradation assay, the unpaired Student's t-test was used. In all tests, values of $p<0.05$ were considered significant.

Received: 14 May 2019; Accepted: 4 December 2019;

Published online: 28 January 2020

\section{References}

1. Mulligan, C. N. Environmental applications for biosurfactants. Environ. Pollut. 133, 183-198 (2005).

2. Satpute, S. K., Banpurkar, A. G., Dhakephalkar, P. K., Banat, I. M. \& Chopade, B. A. Methods for investigating biosurfactants and bioemulsifiers: a review. Crit. Rev. Biotechnol. 30, 127-144 (2010).

3. Banat, I. M. 97/02677 Microbial production of surfactants and their commercial potential. Fuel Energy Abstr. 38, 221 (1997).

4. Cameotra, S. S. \& Makkar, R. S. Recent applications of biosurfactants as biological and immunological molecules. Curr. Opin. Microbiol. 7, 262-266 (2004). 
5. Nitsche, M., Siddhartha, G. A. O. \& Contiero, J. Ramnolipid surfactants: an update on the general aspects of these remarcable biomolecules. Biotechnol Prog. 21, 1593-1600 (2005).

6. Satpute, S. K. et al. Molecular genetics of biosurfactant synthesis in microorganisms. Adv. Exp. Med. Biol. 672, 14-41 (2010).

7. Santos, D. K. F., Rufino, R. D., Luna, J. M., Santos, V. A. \& Sarubbo, L. A. Biosurfactants: Multifunctional biomolecules of the 21st century. International Journal of Molecular Sciences 17 (2016).

8. Banat, I. M., Satpute, S. K., Cameotra, S. S., Patil, R. \& Nyayanit, N. V. Cost effective technologies and renewable substrates for biosurfactants' production. Frontiers in Microbiology 5 (2014).

9. Kubicki, S. et al. Marine biosurfactants: biosynthesis, structural diversity and biotechnological applications. Marine Drugs. https:// doi.org/10.3390/md17070408 (2019).

10. Chong, H. \& Li, Q. Microbial production of rhamnolipids: Opportunities, challenges and strategies. Microbial Cell Factories 16 (2017)

11. Nitschke, M. \& Costa, S. G. V. A. O. Biosurfactants in food industry. Trends Food Sci. Technol. 18, 252-259 (2007).

12. Lourith, N. \& Kanlayavattanakul, M. Natural surfactants used in cosmetics: Glycolipids. Int. J. Cosmet. Sci. 31, 255-261 (2009).

13. Ramkrishna. Biosurfactants, https://doi.org/10.1007/978-1-4419-5979-9 (2010).

14. Rodrigues, L., Banat, I. M., Teixeira, J. \& Oliveira, R. Biosurfactants: Potential applications in medicine. J. Antimicrob. Chemother. 57, 609-618 (2006)

15. Costa, S. G. V. A. O., Nitschke, M., Haddad, R., Eberlin, M. N. \& Contiero, J. Production of Pseudomonas aeruginosa LBI rhamnolipids following growth on Brazilian native oils. Process Biochem. 41, 483-488 (2006).

16. Makkar, R. \& Cameotra, S. An update on the use of unconventional substrates for biosurfactant production and their new applications. Appl. Microbiol. Biotechnol. 58, 428-434 (2002).

17. Rahman, K. S. M., Rahman, T. J., McClean, S., Marchant, R. \& Banat, I. M. Rhamnolipid Biosurfactant Production by Strains of Pseudomonas aeruginosa Using Low-Cost Raw Materials. Biotechnol. Prog. 18, 1277-1281 (2002).

18. Banat, I. M., Makkar, R. S. \& Cameotra, S. S. Potential commercial applications of microbial surfactants. Appl. Microbiol. Biotechnol. 53, 495-508 (2000).

19. Kosaric, N. Biosurfactants and their applications for soil bioremediation. Food Technol. Biotechnol. 39, 295-304 (2001).

20. Lima, T. M. S. et al. Biodegradability of bacterial surfactants. Biodegradation 22, 585-592 (2011).

21. Daniel, R. The metagenomics of soil. Nat. Rev. Microbiol. 3, 470-478 (2005).

22. Berini, F., Casciello, C., Marcone, G. L. \& Marinelli, F. Metagenomics: novel enzymes from non-culturable microbes. 1-19, https:// doi.org/10.1093/femsle/fnx211 (2017).

23. Nandasena, K. et al. Complete genome sequence of Mesorhizobium ciceri bv. biserrulae type strain (WSM1271 T). Stand. Genomic Sci. 9, 462-472 (2014).

24. Thies, S. et al. Metagenomic discovery of novel enzymes and biosurfactants in a slaughterhouse biofilm microbial community. Sci. Rep. 6, 27035 (2016).

25. Ijaq, J., Chandrasekharan, M., Poddar, R., Bethi, N. \& Sundararajan, V. S. Annotation and curation of uncharacterized proteinschallenges. Frontiers in Genetics. https://doi.org/10.3389/fgene.2015.00119 (2015).

26. Desler, C., Durhuus, J. A. \& Rasmussen, L. J. Genome-wide screens for expressed hypothetical proteins. Methods Mol. Biol., https:// doi.org/10.1007/978-1-61779-424-7_3 (2012).

27. Kebbouche-Gana, S. et al. Isolation and characterization of halophilic Archaea able to produce biosurfactants. J. Ind. Microbiol. Biotechnol. 36, 727-738 (2009).

28. Gutierrez, M. C., Kamekura, M., Holmes, M. L., Dyall-Smith, M. L. \& Ventosa, A. Taxonomic characterization of Haloferax sp. ('H. alicantei') strain Aa 2.2: Description of Haloferax lucentensis sp. nov. Extremophiles 6, 479-483 (2002).

29. Al-Mailem, D. M., Eliyas, M. \& Radwan, S. Enhanced bioremediation of oil-polluted, hypersaline, coastal areas in Kuwait via vitamin-fertilization. Environ. Sci. Pollut. Res. 21, 3386-3394 (2014).

30. Kebbouche-Gana, S. et al. Production of biosurfactant on crude date syrup under saline conditions by entrapped cells of Natrialba sp. strain E21, an extremely halophilic bacterium isolated from a solar saltern (Ain Salah, Algeria). Extremophiles 17, 981-993 (2013).

31. van Beilen, J. B., Wubbolts, M. G. \& Witholt, B. Genetics of alkane oxidation by Pseudomonas oleovorans. Biodegradation 5, 161-174 (1994).

32. Smits, T. H. M., Balada, S. B., Witholt, B. \& Beilen, J. B. Van \& Acteriol. J. B. Functional Analysis of Alkane Hydroxylases from GramNegative and Gram-Positive Bacteria. 184, 1733-1742 (2002).

33. Wu, Y. S. et al. Anticancer activities of surfactin potential application of nanotechnology assisted surfactin delivery. Frontiers in Pharmacology 8, (2017).

34. Avigad, L. S. Produced by Bacillus subtilis. 361-369 (1970).

35. Sieber, T. et al. Intrinsic disorder in the common N-terminus of human adenovirus 5 E1B-55K and its related E1BN proteins indicated by studies on E1B-93R. Virology 418, 133-143 (2011).

36. Gudiña, E. J. et al. Novel bioemulsifier produced by a Paenibacillus strain isolated from crude oil. Microb. Cell Fact. 14, 1-11 (2015).

37. Ben Hamed, S. Screening of potential biosurfactant-producing bacteria isolated from seawater biofilm. African J. Biotechnol. 11 (2012).

38. Dusane, D. H. et al. Quorum sensing: Implications on rhamnolipid biosurfactant production. Biotechnol. Genet. Eng. Rev. 27, 159-184 (2010).

39. Saimmai, A., Kaewrueng, J. \& Maneerat, S. Used lubricating oil degradation and biosurfactant production by SC-9 consortia obtained from oil-contaminated soil. Ann. Microbiol. 62, 1757-1767 (2012).

40. Chandankere, R. et al. Properties and characterization of biosurfactant in crude oil biodegradation by bacterium Bacillus methylotrophicus USTBa. Fuel 122, 140-148 (2014).

41. Karlapudi, A. P. et al. Role of biosurfactants in bioremediation of oil pollution-a review. Petroleum 4 (2018).

42. Rontani, J. F. \& Giusti, G. Study of the biodegradation of poly-branched alkanes by a marine bacterial community. Mar. Chem. 20, 197-205 (1986).

43. Jain, D. K., Collins-Thompson, D. L., Lee, H. \& Trevors, J. T. A drop-collapse test for screening surfactant producing microorganisms. J. Microbiol. Methods 13, 271-279 (1991).

44. Iqbal, S., Khali, Z. M. \& Malik, K. A. Enhanced biodegradation and emulsification of crude oil and hyperproduction of biosurfactant by gamma ray - induced mutant of Pseudomanas aerugiona. Appl. Microbiol. Biotechnol. 176-179 (1995).

45. Morikawa, M. et al. A new lipopeptide biosurfactant produced by Arthrobacter sp. strain MIS38. J. Bacteriol. 175, 6459-6466 (1993).

46. Sievers, F. et al. Fast, scalable generation of high-quality protein multiple sequence alignments using Clustal Omega. Mol. Syst. Biol. 7 (2011).

47. Kumar, S., Stecher, G. \& Tamura, K. MEGA7: Molecular Evolutionary Genetics Analysis Version 7.0 for Bigger Datasets. Mol. Biol. Evol. 33, 1870-1874 (2016)

48. Sheffield, P., Garrard, S. \& Derewenda, Z. Overcoming expression and purification problems of RhoGDI using a family of [ldquo] parallel[rdquo] expression vectors. Protein Expr. Purif. 15, 34-39 (1999).

49. Vater, J., Wilde, C., Franke, P., Mehta, N. \& Cameotra, S. S. Matrix-Assisted Laser Desorption Ionization-Time of Flight Mass Spectrometry of Lipopeptide Biosurfactants in Whole Cells and Culture Filtrates of. Society 68, 6210-6219 (2002). 
50. Morikawa, M., Hirata, Y. \& Imanaka, T. A study on the structure \& function relationship of lipopeptide biosurfactants. Biochim. Biophys. Acta (BBA)-Molecular Cell Biol. Lipids 1488, 211-218 (2000).

51. Dörr de Quadros, P. et al. Oily sludge stimulates microbial activity and changes microbial structure in a landfarming soil. Int. Biodeterior. Biodegrad. 115, 90-101 (2016).

52. Cerqueira, V. S. et al. Biodegradation potential of oily sludge by pure and mixed bacterial cultures. Bioresour. Technol. 102, 11003-11010 (2011)

53. Grassi, M. T., Ferreira, V. R., Silva, C. A., da, Gouveia, C. D. \& Fernandes, A. N. Optimization of an analytical protocol for the extraction, fractionation and determination of aromatic and aliphatic hydrocarbons in sediments. J. Braz. Chem. Soc. 23, 1460-1468 (2012).

54. Hu, J. et al. Membrane Proteins of the Endoplasmic Reticulum Induce High-Curvature Tubules. Science (80-.). 319, 1247-1250 (2008).

55. Roy, E., Secretary, H. \& Golledge Commissioner, R. W. Method for the determination of extractable petroleum hydrocarbons (EPH) Massachusetts Department of Environmental Protection Division of Environmental Analysis (Senator William X. Wall Experiment Station). (2004).

56. Aly Salem, D. M. S., Morsy, F. A. E. M., El Nemr, A., El-Sikaily, A. \& Khaled, A. The monitoring and risk assessment of aliphatic and aromatic hydrocarbons in sediments of the Red Sea, Egypt. Egypt. J. Aquat. Res. 40, 333-348 (2014).

57. Sar, P. et al. Biostimulation and bioaugmentation of native microbial community accelerated bioremediation of oil refinery sludge. Bioresour. Technol. 253, 22-32 (2018).

\section{Acknowledgements}

This work was supported by the Conselho Nacional de Desenvolvimento Científico e Tecnológico (CNPq-Brazil), Coordenação de Aperfeiçoamento de Pessoal de Nível Superior (CAPES-Brazil).

\section{Author contributions}

S.C.S.A. conducted the studies, performing the experiments, evaluation of results and writing the manuscript. R.C.B.S.P. and D.C.L. helped in the carry out of the cloning experiments and biosurfactant purification; U.B.S. performed the metagenomic library construction; M.M.B.F. performed in the bioinformatic analyses, W.J.A. helped in the biosurfactant activity assays; AP.N., E.P. and M.H.V. assisted in the hydrocarbon degradation assay by gas chromatography; L.F.A.L. was responsible by the conception of this research, design of experiments and writing of the manuscript. All authors assisted with editing/writing and in approval of the final manuscript.

\section{Competing interests}

The authors declare no competing interests.

\section{Additional information}

Supplementary information is available for this paper at https://doi.org/10.1038/s41598-020-58330-X.

Correspondence and requests for materials should be addressed to L.F.A.-L.

Reprints and permissions information is available at www.nature.com/reprints.

Publisher's note Springer Nature remains neutral with regard to jurisdictional claims in published maps and institutional affiliations.

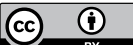

Open Access This article is licensed under a Creative Commons Attribution 4.0 International License, which permits use, sharing, adaptation, distribution and reproduction in any medium or format, as long as you give appropriate credit to the original author(s) and the source, provide a link to the Creative Commons license, and indicate if changes were made. The images or other third party material in this article are included in the article's Creative Commons license, unless indicated otherwise in a credit line to the material. If material is not included in the article's Creative Commons license and your intended use is not permitted by statutory regulation or exceeds the permitted use, you will need to obtain permission directly from the copyright holder. To view a copy of this license, visit http://creativecommons.org/licenses/by/4.0/.

(C) The Author(s) 2020 